\title{
Effects of supplementing laying hen diets with different proprietary vitamin-mineral premixes and housing systems on egg properties and shelf-life stability Ogunwole, O. A. Agricultural Biochemistry and Nutrition Unit, Department of Animal Science, University of Ibadan, Ibadan, Nigeria Abstract Email:droaogunwole@gmail.com; 2348128799912
}

Egg quality and durability have been directly linked to the nutrition of laying hen thus, the effects of five different supplemental vitamin-mineral premixes $(\mathrm{VmP})$ in the diets of laying hens housed in battery cage $(B C)$ and deep litter $(D L)$ on the egg properties and shelf life stability in 0, 7, 14, 21 and 28 days of egg storage (DOS) were investigated in this study. In a 4-week feeding trial, Bovans Nera Black laying hens $(n=480)$ aged 71-week were allocated to five treatments in each housing system (HS) (BC and DL). Each treatment was replicated six times and a replicate comprised eight hens. The basal isocaloric and isonitrogenous diet was appropriately supplemented with $0.25 \%$ of any of the five proprietary $V m P$ and the diets were offered with water ad libitum to respective experimental hens in both HS. The experiment was a $2 \times 5 \times 5$ factorial arrangement in a completely randomized design (2 HS X $5 \mathrm{VmP} X 5 \mathrm{DOS})$. Foaming capacity, foaming stability, viscosity, emulsion stability, least gelation concentration and shelf life stability of egg white and whole egg from both HS decreased significantly $(P<0.05)$ in DOS while the thiobarbituric acid reactive substances (TBARSmg/MA/100g) increased in DOS. The TBARS of respective whole and egg white from hens fed VmP1 (0.048 and 0.051), 2 (0.049 and 0.054), 3(0.056 and 0.155), 4(0.156 and $0.156)$ and $5(0.153$ and 0.151$)$ differed significantly $(P<0.05)$. Interactions of HSXVmP, HS $X D O S$ on all attributes of both whole and egg white, except specific gravity and emulsion capacity, were significantly different $(P<0.05)$. Eggs deteriorated in DOS irrespective of dietary VmP or HS but much more for eggs from DL compared with BC.

Keywords: Dietary vitamin-mineral premixes, Whole or egg white, Laying hens, Thiobarbituric acid reactive substances, Functional properties

\section{Introduction}

Poultry egg is important in many spheres of the modern food industry (Montagne, 2001) and is widely used due to their multifunctional properties such as foaming, gelling and emulsification (HernandezLedesma and Cha Chien, 2013). According to Beneda et al. (2014), egg, either as a whole or its constituents (egg yolk and white) is a key ingredient in many food products by virtue of its nutritional value and unique functional properties such as foaming, gelling and emulsification. Eggs also serve as a raw material for the pharmaceutical and cosmetic industries due to its peculiar functional properties (Matt et al., 2009).

Egg quality and durability have been directly linked to the nutrition of laying hen (Patricio, 2003). The diet and housing system (HS) of the laying hens can greatly affect the nutritional quality and other properties of the eggs (Aro et al., 2011). Among the dietary factors affecting the nutritional value of egg and keeping quality includes vitamins, minerals and fat (Hayat et al., 2010). The quality of chicken eggs starts to decrease immediately after it is laid. These chemical changes in eggs can be delayed but not completely prevented (Theoron et al., 2003). Specially, birds in cages require more attention for supplying 
vitamin-mineral premix ( $\mathrm{VmP})$ than those of floor housing because of more limited opportunity for coprophagy for birds raised on the deep litter (DL).

Therefore, vitamin and mineral are important in poultry production (Asaduzzaman et al., 2005). Studies have been carried out on the different commercial VmP (Ogunwole et al., 2012) as well as management systems in poultry production (Alamprese et al., 2012). However, in the recent times, studies have not been carried out on management systems and the relative effect of $\mathrm{VmP}$ on functional properties and keeping quality of table eggs laid by the hen at the late stage. A study conducted by Alamprese et al. (2012), was mainly on the effect of HS, diet, hen ages and storage on egg properties. The interactive effect of hen age, storage time and storage temperature on interior egg quality has also been evaluated (Hasan and Aylin, 2009). These studies were in other climes with dearth of information on what is obtainable here in the tropics. There was also no report on the effect of $\mathrm{VmP}$ used in formulating feed fed to birds as well as the interactive effect of $\mathrm{VmP}$, HS and DOS on egg functional properties and shelf life stability in phases of laying. Therefore, this study was aimed at determining the functional properties of eggs produced in two HS using five different dietary VmP supplements in DOS.

\section{Materials and methods Experimental site}

The experiment was conducted at the Poultry Unit of the Teaching and Research Farm, University of Ibadan, situated in the derived savanna vegetation belt of Nigeria. The geographical location is longitude $7^{0}$ 27.05 North and latitude $3^{0} 53.74$ of the Greenwich Meridian East at an altitude above $200 \mathrm{~m}$ sea level. Average temperature and relative humidity of the location is about $23-25^{\circ} \mathrm{C}$ and $60 \%$, respectively.

\section{Experimental birds and management}

Bovan Nera black hens $(\mathrm{N}=480)$ at week 51 (mid stage of laying) with a track record of medication, vaccination schedule and productive performance from one-day old were used for the experiment. Hens' management was under two HS (deep litter, DL and battery cage, BC) with equal exposure to similar environment all through the period of the experiment. Birds were randomly allotted to five dietary treatments. Each treatment was replicated six times with eight birds per replicate. Two hundred and forty hens were each raised in an opensided DL house with average floor space area of each partitioned pen measuring $3.32 \mathrm{~m}^{2}$ and a conventional BC. The BC was a three tier cage each measuring $40 \times 41 \times 32$ $\mathrm{cm}^{3}$. The cages were arranged in rows placed on leg supports so the floors of the cages were about 61.00 to $91.44 \mathrm{~cm}$ above ground with a rectangular hollow in the middle to collect the droppings.

\section{Experimental diets}

Five isocaloric and isonitrogenous diets were formulated. Each diet was supplemented with one of the five proprietary $\mathrm{VmP}$ purposively selected among those most commonly used in formulating layer's feed and incorporated at $0.25 \%$. Gross formulation of the experimental diet is shown in Table 1 while the composition of the different dietary $\mathrm{VmP}$ as indicated on their individual labels is shown in Table 2. Detailed dietary formulation of the experimental diets (Table 1) and composition of test vitaminmineral premixes as shown on their labels (Table 2) have been documented elsewhere (Ogunwole et al., 2015a, b). 


\section{Ogunwole}

Table 1: Gross composition (\%) of the experimental laying chicken diets

\begin{tabular}{lrrrrr}
\hline Ingredients & T1 & T2 & T3 & T4 & T5 \\
\hline Maize & 59.00 & 59.00 & 59.00 & 59.00 & 59.00 \\
Soybean meal & 24.37 & 24.37 & 24.37 & 24.37 & 24.37 \\
Wheat bran & 3.00 & 3.00 & 3.00 & 3.00 & 3.00 \\
Palm kernel cake & 3.00 & 3.00 & 3.00 & 3.00 & 3.00 \\
Table salt & 0.30 & 0.30 & 0.30 & 0.30 & 0.30 \\
Di-calcium phosphate & 0.11 & 0.11 & 0.11 & 0.11 & 0.11 \\
Limestone & 9.30 & 9.30 & 9.30 & 9.30 & 9.30 \\
Biotronics & 0.30 & 0.30 & 0.30 & 0.30 & 0.30 \\
Mycofix & 0.10 & 0.10 & 0.10 & 0.10 & 0.10 \\
DL-Methionine & 0.15 & 0.15 & 0.15 & 0.15 & 0.15 \\
L-Lysine & 0.12 & 0.12 & 0.12 & 0.12 & 0.12 \\
VmP 1 & 0.25 & - & - & - & - \\
VmP 2 & - & 0.25 & - & - & - \\
VmP 3 & - & - & 0.25 & - & - \\
VmP 4 & - & - & - & 0.25 & - \\
VmP 5 & - & - & - & & 0.25 \\
Total & $\mathbf{1 0 0 . 0 0}$ & $\mathbf{1 0 0 . 0 0}$ & $\mathbf{1 0 0 . 0 0}$ & $\mathbf{1 0 0 . 0 0}$ & $\mathbf{1 0 0 . 0 0}$ \\
Calculated nutrients & & & & & $2,687.56$ \\
ME (Kcal/kg) & 2687.56 & 2687.56 & 2687.56 & 2687.56 & 17.00 \\
Crude protein (\%) & 17.00 & 17.00 & 17.00 & 17.00 & 3.80 \\
Crude fibre (\%) & 3.80 & 3.80 & 3.80 & 3.80 & 3.59 \\
Fat (\%) & 3.59 & 3.59 & 3.59 & 3.59 & 0.97 \\
Lysine (\%) & 0.97 & 0.97 & 0.97 & 0.71 & 0.71 \\
Methionine+Cystein (\%) & 0.71 & 0.71 & 0.71 & 3.68 & 3.68 \\
Calcium (\%) & 3.68 & 3.68 & 3.68 & 0.40 & 0.40 \\
Available Phosphorus (\%) & 0.40 & 0.40 & 0.40 & & - \\
\hline
\end{tabular}

$V m P=$ Vitamin-mineral premix $; M E=$ Metabolizable Energy. T1, T2, T3, T4 and T5: Respective experimental diets supplemented with the different proprietary vitamin-mineral premixes

Table 2: Gross composition of test ingredient vitamin-mineral layer premixes

\begin{tabular}{|c|c|c|c|c|c|}
\hline \multirow[b]{2}{*}{ Vitamins \& Minerals } & \multicolumn{5}{|c|}{ Test proprietary vitamin-mineral premixes } \\
\hline & 1 & 2 & 3 & 4 & 5 \\
\hline Vitamin A (IU) & $10,000,000$ & $10,000,000$ & $10,000,000$ & $12,000,000$ & $10,000,000$ \\
\hline Vitamin D3 (IU) & $2,000,000$ & $2,000,000$ & $2,000,000$ & $2,400,000$ & $2,000,000$ \\
\hline Vitamin E (IU) & 12,000 & 12,000 & 12,000 & 12,000 & 23,000 \\
\hline Vitamin K (mg) & 2,000 & 2,000 & 2,000 & 2,000 & 2,000 \\
\hline Vitamin B1 (mg) & 1,500 & 1,500 & 1,500 & 1,500 & 3,000 \\
\hline Vitamin B2 (mg) & 5,000 & 4,000 & 5,000 & 4,000 & 6,000 \\
\hline Vitamin B6 (mg) & 1,500 & 1,500 & 1,500 & 1,800 & 5,000 \\
\hline Vitamin B12 (mg) & 10 & 10 & 10 & 10 & 25 \\
\hline Niacin (mg) & 15,000 & 15,000 & 15,000 & 25,000 & 50,000 \\
\hline Pantothenic acid (mg) & 5,000 & 5,000 & 5,000 & 5,000 & 10,000 \\
\hline Folic acid $(\mathrm{mg})$ & 600 & 500 & 600 & 500 & 1,000 \\
\hline Biotin (mg) & 20 & 20 & 20 & 25 & 50 \\
\hline Choline chloride (mg) & 150,000 & 100,000 & 150,000 & 240 & 400,000 \\
\hline Manganese (mg) & 80,000 & 75,000 & 75,000 & 80,000 & 120,000 \\
\hline Zinc (mg) & 60,000 & 50,000 & 50,000 & 50,000 & 80,000 \\
\hline Iron (mg) & 40,000 & 20,000 & 25,000 & 20,000 & 100,000 \\
\hline Copper (mg) & 8,000 & 5,000 & 5,000 & 5,000 & 8,500 \\
\hline Iodine (mg) & 1,000 & 1,000 & 1,000 & 1,200 & 1,500 \\
\hline Selenium (mg) & 150 & 200 & 100 & 200 & 120 \\
\hline Cobalt (mg) & 250 & 500 & 400 & 200 & 300 \\
\hline Antioxidant (mg) & 100,000 & 125,000 & 125,000 & 125,000 & 120,000 \\
\hline
\end{tabular}




\section{Experimental design and model}

The experiment was a $2 \times 5 \times 5$ factorial arrangement in a completely randomized design which comprised two HS (BC and $\mathrm{DL})$, five different $\mathrm{VmP}$ and five $(0,7,14$, 21, and 28) different DOS of eggs obtained from the birds fed the five $\mathrm{VmP}$.

\section{Parameters measured}

A total of 459 freshly laid eggs (eggs per treatment) were collected and labeled appropriately for analysis and 45 eggs each were analyzed within 48 hours of the respective days $(0,7.14,21$ and 28) of storage. Storage durations were selected to simulate likely days of consumer storage of shell eggs. Three eggs per treatment were manually cracked with the yolks and chalazae removed using an egg yolk separator and the albumen pooled together to take measurements of parameters on the egg white. Another three were manually broken and pooled together to take measurements of parameters on the whole egg.

\section{Functional properties \\ Foam capacity (FC) and stability}

Foam capacity and stability were evaluated according to the method of Coffman and Garcia (1997), with slight modifications. $50 \mathrm{~mL}$ of each pool of eggs was whipped with $100 \mathrm{~mL}$ distilled water for $5 \mathrm{~min}$ in a Kenwood blender at speed setting 1-li" and was poured into a $250 \mathrm{~mL}$ graduated cylinder.

Volume Increase (\%) was calculated using $\mathrm{t} \mathrm{h} \mathrm{e} \quad \mathrm{e} \mathrm{q} \mathrm{u} \mathrm{a} \mathrm{t}$ i o $\mathrm{n}$ : Volume Increase $(\%) \mathrm{V}=$

Volume after whipping $(\mathrm{mL})$ - Volume before whipping $(\mathrm{mL}) \times 100$ Volume before whipping $(\mathrm{mL})$

Foam stability was measured with a graduated cylinder after the foam had been allowed to rest for one hour, as described by Lomakina and Mikova (2006), using a small volume. Foam stability was measured in the same vessel as the volume of released fluid at the bottom one hour after whipping. Foam stability was calculated as:

Foam stability $(\%)=\mathrm{Vs} / \mathrm{Vt} \times 100$

Where $\mathrm{Vs}$ is the volume of the liquid albumen separated and $\mathrm{Vt}$ is the total volume of albumen originating the volume of foam transferred into the conical vessel. This process was carried out for egg albumen and whole egg, and repeated on 0 , 7, 14, 21 and 28 DOS. All measurements were taken in triplicates.

\section{Gelation properties}

Gelation properties were evaluated using the method described by Coffman and Garcia (1977). Sample suspensions of 2$20 \%$ were prepared in distilled water. 10 $\mathrm{mL}$ of each of the prepared dispersions was transferred into a test tube. It was heated in a boiling water bath for $1 \mathrm{hr}$, followed by rapid cooling in a bath of cold water. The test tubes were further cooled at $4^{\circ} \mathrm{C}$ for $2 \mathrm{~h}$.

\section{Least gelation concentration}

The least gelation concentration was determined as the concentration of sample from the inverted test tube which did not slip or fall. This process was carried out for egg albumen and whole egg, and repeated on $0,7,14,21$ and 28 DOS. All measurements were in triplicates.

\section{Emulsion capacity and stability}

\section{Emulsion capacity}

Preparation of the emulsion capacity was carried out according to the method of Beuchat (1997) with some modifications. $50 \mathrm{~mL}$ of egg sample and $100 \mathrm{~mL}$ distilled water was blended for 30 seconds in a Philip's blender at $1600 \mathrm{rpm}$. While blending continued, vegetable oil was added in $5 \mathrm{~mL}$ portions from a burette. Blending did not stop until the emulsion breakpoint, a separation into two livers, was reached.Emulsification determinations were carried out at room temperature (28 ${ }^{\circ} \mathrm{C}$ ). Emulsion capacity was expressed as the amount of oil emulsified and held per 


\section{Ogunwole}

gram of sample (Beuchat, 1977). This process was carried out for egg albumen and whole egg, and repeated on $0,7,14,21$ and 28 DOS. All measurements were in triplicates.

\section{Emulsion stability}

The emulsion stability was determined using the sample prepared for emulsion capacity measurement. Samples were heated for $15 \mathrm{~min}$ at $85{ }^{\circ} \mathrm{C}$ cooled and divided evenly into to $50 \mathrm{~mL}$ centrifuge tubes. Samples were then centrifuged at $1100 \mathrm{rpm}$ for $5 \mathrm{~min}$. The emulsion stability was expressed as percentage of emulsifying activity remaining after heating. This process was carried out for egg albumen and whole egg, and repeated on $0,7,14,21$ and 28 DOS. All measurements were taken in triplicates.

\section{Viscosity}

The viscosity was measured using a viscometer. An arm of the viscometer was filled with some quantity of egg sample. A finger was used to cover the measuring arm of the viscometer which has two marks (one above and another below, point $\mathrm{A}$ and $\mathrm{B}$ ). The finger was released and the time taken for the egg sample to move from point A to $B$ was noted and the viscosity was measured as follows:

$\mathrm{V}=\mathrm{tK}$

Where $\mathrm{v}=$ viscosity,

$\mathrm{t}=$ time taken and

$\mathrm{K}=$ constant.

This process was carried out for egg albumen and whole egg, and repeated on 0 , 7, 14, 21 and 28 DOS.

Degree of lipid oxidation was estimated in egg albumen and whole egg, and repeated on $0,7,14,21$ and 28 DOS in triplicates as described (Pensel, 1990). The TBA of each sample was calculated with the formula. TBA mg MA/g=KxO.D. $530 \mathrm{~nm}$ where $\mathrm{k}=9.242, \mathrm{MA}=$ Malonaldehyde.

\section{Specific gravity}

The specific gravity was measured using a pycnometer (specific gravity bottle). Empty pycnometer was first weighed and the weight noted. Water was poured into the bottle and weighed after which the egg sample was poured into the bottle and also weighed. The specific gravity was then calculated with the formula:

Specific gravity $=\underline{\mathrm{WS}}$

$$
\overline{\mathrm{WW}}
$$

Where Ws is the weight of the sample and Ww is the weight of water.

This process was carried out for egg albumen and whole egg, and repeated on 0 , 7, 14, 21 and 28 DOS. All measurements were in triplicates.

\section{Statistical analysis}

Data were subjected to analysis of variance using the General Linear Model procedures (SAS, 2012). Means were separated using Least Significant Difference test of the same software at $\alpha_{0.05}$.

\section{Results \\ Specific gravity and functional properties of egg white}

Effect of five proprietary $\mathrm{VmP}$, HS and DOS on the specific gravity and functional properties of egg white is shown in Table 3. The specific gravity of eggs differed significantly $(\mathrm{P}<0.05)$ between the $\mathrm{BC}$ and DL. However, there was no significant effect $(\mathrm{P}>0.05)$ of $\mathrm{VmP}$ and DOS on specific gravity of egg white.

Both HS (DL and BC) and VmP affected foaming capacity of egg white significantly $(\mathrm{P}<0.05)$. Foaming capacity of egg white from hens fed $\mathrm{VmP} 3(62.88 \%)$ was significantly higher $(\mathrm{P}<0.05)$ compared with those on VmP 1 (24.68), 2 (41.06), 4 $(43.55)$ and $5(33.15 \%)$ which in turn differed significantly $(\mathrm{P}<0.05)$ from one another. The DOS had significant effect $(\mathrm{P}<0.05)$ on foaming capacity of egg white. 
The HS, VmP and DOS significantly affected $(\mathrm{P}<0.05)$ the foaming stability of egg white. Birds fed VMP 2 had significantly higher foaming stability (70.63) compared with those from VMP 1 (40.77), 3 (64.29), 4 (31.61) and 5 (25.17). Viscosity was higher $(\mathrm{P}<0.05)$ in egg white from DL (27.82) than those from $B C$ (26.90). Viscosity was highest $(\mathrm{P}<0.05)$ in eggs from hens fed VmP1 (33.62) compared with those on VmP 2 (28.28), 3
(27.29), 4 (24.71) and 5 (22.81). Viscosity in storage day zero was higher (47.97) $(\mathrm{P}<0.05)$ than those on days 7 (27.09), 14 (23.87), 21 (20.71) and 28 (17.15)

Interaction between HS and treatment, HS and DOS and HS and VmP and DOS on foaming capacity, foaming stability and viscosity were highly significant $(\mathrm{P}<0.01)$. However, the interactions were not significant $(\mathrm{P}>0.05)$ for specific gravity of egg white.

Table 3: Effect of housing systems, vitamin- mineral premixes and duration of storage on specific gravity and functional properties of egg white

\begin{tabular}{|c|c|c|c|c|c|}
\hline & Factors & $\begin{array}{l}\text { Specific } \\
\text { gravity } \\
\left(\mathrm{g} / \mathrm{cm}^{3}\right) \\
\end{array}$ & $\begin{array}{l}\text { Foaming } \\
\text { capacity } \\
(\%)\end{array}$ & $\begin{array}{l}\text { Foaming } \\
\text { instability } \\
(\%)\end{array}$ & $\begin{array}{l}\text { Viscosity } \\
\text { (CentiStokes) }\end{array}$ \\
\hline \multirow{3}{*}{$\begin{array}{l}\text { Housing } \\
\text { system }\end{array}$} & Battery Cage & $1.18^{\mathrm{a}}$ & $41.62^{\mathrm{a}}$ & $46.23^{\mathrm{b}}$ & $26.90^{\mathrm{b}}$ \\
\hline & Deep litter & $1.12^{\mathrm{b}}$ & $40.50^{\mathrm{b}}$ & $46.76^{\mathrm{a}}$ & $27.82^{\mathrm{a}}$ \\
\hline & SEM & 0.02 & 0.03 & 0.02 & 0.03 \\
\hline \multirow{6}{*}{$\begin{array}{l}\text { Vitamin- } \\
\text { mineral } \\
\text { premix }\end{array}$} & 1 & $1.15^{\mathrm{a}}$ & $24.68^{\mathrm{e}}$ & $40.77^{\mathrm{c}}$ & $33.62^{\mathrm{a}}$ \\
\hline & 2 & $1.15^{\mathrm{a}}$ & $41.06^{\mathrm{c}}$ & $70.63^{a}$ & $28.28^{\mathrm{b}}$ \\
\hline & 3 & $1.17^{\mathrm{a}}$ & $62.88^{\mathrm{a}}$ & $64.29^{\mathrm{b}}$ & $27.29^{c}$ \\
\hline & 4 & $1.14^{\mathrm{a}}$ & $43.55^{\mathrm{b}}$ & $31.61^{\mathrm{d}}$ & $24.71^{\mathrm{d}}$ \\
\hline & 5 & $1.14^{\mathrm{a}}$ & $33.15^{\mathrm{d}}$ & $25.17^{\mathrm{e}}$ & $22.89^{\mathrm{e}}$ \\
\hline & SEM & 0.02 & 0.04 & 0.04 & 0.03 \\
\hline \multirow{14}{*}{$\begin{array}{l}\text { Duration of } \\
\text { storage }\end{array}$} & 0 & $1.19^{\mathrm{a}}$ & $58.55^{\mathrm{a}}$ & $60.64^{\mathrm{a}}$ & $47.97^{\mathrm{a}}$ \\
\hline & 7 & $1.13^{\mathrm{a}}$ & $41.91^{\mathrm{b}}$ & $41.99^{d}$ & $27.09^{b}$ \\
\hline & 14 & $1.14^{\mathrm{a}}$ & $37.35^{\mathrm{c}}$ & $49.22^{\mathrm{b}}$ & $23.87^{\mathrm{c}}$ \\
\hline & 21 & $1.17^{\mathrm{a}}$ & $35.35^{\mathrm{d}}$ & $43.15^{\mathrm{c}}$ & $20.21^{\mathrm{d}}$ \\
\hline & 28 & $1.12^{\mathrm{a}}$ & $32.15^{\mathrm{e}}$ & $37.47^{\mathrm{e}}$ & $17.15^{\mathrm{e}}$ \\
\hline & SEM & 0.02 & 0.04 & 0.04 & 0.05 \\
\hline & Source of variation & & & & \\
\hline & HS & 0.001 & $<0.001$ & $<0.001$ & $<0.001$ \\
\hline & Treatment & $0.584^{\mathrm{NS}}$ & $<0.001$ & $<0.001$ & $<0.001$ \\
\hline & DOS & $0.059^{\mathrm{NS}}$ & $<0.001$ & $<0.001$ & $<0.001$ \\
\hline & HS*Treatment & $0.593^{\mathrm{NS}}$ & $<0.001$ & $<0.001$ & $<0.001$ \\
\hline & HS*DOS & $0.313^{\mathrm{NS}}$ & $<0.001$ & $<0.001$ & $<0.001$ \\
\hline & Treatment*DOS & $0.440^{\mathrm{NS}}$ & $<0.001$ & $<0.001$ & $<0.001$ \\
\hline & HS*Treatment*DOS & $0.444^{\mathrm{NS}}$ & $<0.001$ & $<0.001$ & $<0.001$ \\
\hline
\end{tabular}

$\overline{a-e}$ Means in the same column with different superscripts are significantly different $(\mathbf{P}<0.05)$.. SEM- standard error of mean. NS- not significant. $1 \mathrm{cSt}($ centistoke $)=1 \mathrm{~mm}^{2} / \mathrm{s}, \mathrm{HS}=$ Housing system, DOS=Duration of storage

Functional properties and oxidative stability of egg white

Effect of five proprietary VmP, HS and DOS on functional properties and oxidative stability of egg white are shown in Table 4. Emulsion capacity $(0.33)$ and stability (16.71) of eggs from DL were higher than those from BC (0.25 and 14.92, respectively). Emulsion capacity was highest in eggs of hens fed VmP3 (0.32) which was similar $(\mathrm{P}>0.05)$ to those fed VmP1 (0.35) but higher $(\mathrm{P}<0.05)$ than in eggs from hens on VmP 2 (0.29), 4 (0.24) and 5 (0.24). Emulsion stability was significantly affected $(\mathrm{P}<0.05)$ by $\mathrm{VmP}$ and DOS. Emulsion stability was least on 28 (10.18) and highest at 0 (28.47) DOS.

Eggs from hens on DL had higher least 


\section{Ogunwole}

gelation concentration (6.08) and oxidative stability $(0.06) \quad(\mathrm{P}<0.05)$ compared with those from BC (5.13 and 0.04, respectively). The least gelation concentration and oxidative stability increased significantly in DOS. Oxidative stability were significantly different at 0 (0.008), 7 (0.019), 14 (0.051), 21 (0.078) and $28(0.102 \mathrm{mg} / \mathrm{MA} / 100 \mathrm{~g})$ DOS.

Interactions of $\mathrm{HS} \mathrm{X}$ treatment (HS and DOS) X HS X VmP and DOS on emulsion capacity, emulsion stability, least gelation concentration and oxidative stability (TBARS) of egg white were highly significant $(\mathrm{P}<0.01)$ except for the interaction of HS X treatment which was not significant for emulsion capacity.

Effect of housing system and vitaminmineral premix on egg white characteristics

Effect of HS and VmP on functional and physical attributes of egg under two HS in DOS is shown in Table 5. Specific gravity was not significantly affected $(\mathrm{P}>0.05)$ by the different $\mathrm{VmP}$ in $\mathrm{BC}$. Eggs from hens fed VmP1 and 2 in DL were not statistically different from those on $\mathrm{VmP} 1,2,3,4$ and 5 in $\mathrm{BC}$. The FC, foaming stability, viscosity and emulsion stability were significantly different across all VmP X HS except the interaction of BC X VmP3 (15.90), DL X VmP4 (15.89) and BC X VmP1 (15.82) which were similar $(\mathrm{P}>0.05)$. Highest FC was observed in the interaction of DL X VmP3 (71.12) which was significantly different $(\mathrm{P}<0.05)$ from others across the two HS and was lowest in BC X VmP1 (25.29). Highest foaming stability was observed in the interaction between BC X VmP3 (70.12) which was significantly different $(\mathrm{P}<0.05)$ from the other values across the two HS. However, lowest value was observed in BC X VmP5 (19.11). Emulsion capacity in DL X VmP1 (0.39) was highest and significantly different
$(\mathrm{P}<0.05)$ from others. However, $\mathrm{BC} \mathrm{X}$ $\mathrm{VmP} 2, \mathrm{BC} X \mathrm{VmP} 3$ and DL X VmP 4 with values of 0.27 , respectively were similar $(\mathrm{P}>0.05)$. The highest oxidative stability was observed in DL X VmP5 (0.062) and lowest in BC X VmP1 (0.039). Oxidative stability was similar $(\mathrm{P}>0.05)$ in eggs from $\mathrm{BC} X \mathrm{VmP} 1,2$ and 3.

Effect of housing system and duration of storage on egg white

Effect of HS and DOS on egg white attributes is shown in Table 6. Effect of HS and DOS on specific gravity was not significantly different $(\mathrm{P}>0.05)$. Specific gravity of eggs from hens in $\mathrm{BC}$ at zero DOS was higher and significantly different $(\mathrm{P}<0.05)$ from those in DL at 7, 21 and 28 DOS, but similar $(\mathrm{P}>0.05)$ to other in both HS. FC, foaming stability, viscosity, emulsion capacity and emulsion stability decreased significantly $(\mathrm{P}<0.05)$ in both $\mathrm{BC}$ and DL with increase in DOS from 48.06 to $36.21,63.7$ to $35.81,46.80$ to $16.64,0.43$ to 0.15 and 28.12 to 8.53 , respectively in BC and from 69.04 to 28.10 , 57.42 to $39.12,49.13$ to 17.670 .64 to 0.17 and 28.81 to 11.83 , respectively in DL. The FC, foaming stability, viscosity, emulsion capacity and emulsion stability of eggs from $\mathrm{DL}$ were higher than those from $\mathrm{BC}$ at all DOS and were significantly different $(\mathrm{P}<0.05)$ except for the emulsion capacity at 21 and $28 \mathrm{DOS}$ in $\mathrm{BC}$ which were similar $(\mathrm{P}>0.05)$. The relationships of $\mathrm{FC}$ in egg white in the DOS resulted in quadratic equation as shown in equation 1 below which shows progressive decrease in $\mathrm{FC}$ of egg white in DOS.

$\mathrm{Y}=3 \mathrm{E}-05 \mathrm{x}^{4}-0.0032 \mathrm{x}^{3}+0.0974 \mathrm{x}^{2}-$
$1.3084 \mathrm{x}+{ }^{2}+48.06$
$\left(\mathrm{R}^{2}=0.0996\right) \ldots \ldots \ldots$ Equation 1 Also, the relationship of egg white viscosity as influenced in the DOS is represented by equation 2 below which showed significant quadratic decrease $(\mathrm{P}>0.05)$ in the viscosity 
of egg white with increased DOS

$\mathrm{Y}=0.0004 \mathrm{x}^{4}-0.0261 \mathrm{x}^{3}+0.6142 \mathrm{x}^{2}-6.1313 \mathrm{x}+46.804\left(\mathrm{R}^{2}=0.8793\right)$.. Equation 2 Least gelation concentration and TBARS increased significantly $(\mathrm{P}<0.05)$ in DOS both in $\mathrm{BC}$ and DL. Highest least gelation concentration (9.60) and TBARS (0.12) were observed in eggs from DL at 28 DOS which differed significantly $(\mathrm{P}<0.05)$ from others. Lowest least gelation concentration was in eggs from $\mathrm{BC}$ at zero DOS while lowest TBARS was in eggs from DL at zero DOS. The relationship of TBARS in egg white in the different DOS is represented in equation 3 which revealed that TBARS in egg white increased significantly $(\mathrm{P}<0.05)$ in DOS.

$Y=3 E-07 x^{4}-2 E-05 x^{3}+0.000 x^{2}-0.0018 x+0.0065\left(R^{2}=0.9319\right) \ldots .$. Equation 3

Table 4: Effect of housing systems, vitamin-mineral premixes and duration of storage on functional properties and oxidative stability of egg white

\begin{tabular}{|c|c|c|c|c|c|}
\hline & Factors & $\begin{array}{l}\text { Emulsion } \\
\text { capacity } \\
(\%)\end{array}$ & $\begin{array}{l}\text { Emulsion } \\
\text { stability } \\
(\%)\end{array}$ & $\begin{array}{l}\text { Least Gelation } \\
\text { Concentration }\end{array}$ & $\begin{array}{l}\text { TBARS } \\
(\mathrm{mg} / \mathrm{MA} / 100 \mathrm{~g})\end{array}$ \\
\hline Housing & Battery cage & $0.25^{b}$ & $14.92^{b}$ & $5.13^{b}$ & $0.04^{b}$ \\
\hline \multirow[t]{2}{*}{ system } & Deep litter & $0.33^{\mathrm{a}}$ & $16.71^{\mathrm{a}}$ & $6.08^{\mathrm{a}}$ & $0.06^{\mathrm{a}}$ \\
\hline & SEM & 0.01 & 0.03 & 0.01 & 0.000 \\
\hline Vitamin- & 1 & $0.35^{\mathrm{a}}$ & $17.49^{\mathrm{a}}$ & $3.80^{\mathrm{e}}$ & $0.048^{\mathrm{e}}$ \\
\hline Mineral & 2 & $0.29^{\mathrm{b}}$ & $16.60^{\mathrm{b}}$ & $4.90^{\mathrm{d}}$ & $0.051^{\mathrm{c}}$ \\
\hline \multirow[t]{4}{*}{ Premix } & 3 & $0.32^{\mathrm{ab}}$ & $15.18^{\mathrm{c}}$ & $5.4^{\mathrm{c}}$ & $0.049^{d}$ \\
\hline & 4 & $0.24^{\mathrm{c}}$ & $15.26^{c}$ & $6.50^{\mathrm{b}}$ & $0.054^{\mathrm{b}}$ \\
\hline & 5 & $0.24^{\mathrm{c}}$ & $14.53^{d}$ & $7.42^{\mathrm{a}}$ & $0.056^{\mathrm{a}}$ \\
\hline & SEM & 0.02 & 0.05 & 0.01 & 0.000 \\
\hline Duration of & 0 & $0.54^{\mathrm{a}}$ & $28.47^{\mathrm{a}}$ & $2.82^{\mathrm{e}}$ & $0.008^{\mathrm{e}}$ \\
\hline \multirow[t]{12}{*}{ Storage } & 7 & $0.33^{b}$ & $17.33^{b}$ & $3.80^{\mathrm{d}}$ & $0.019^{d}$ \\
\hline & 14 & $0.23^{\mathrm{c}}$ & $11.94^{\mathrm{c}}$ & $5.40^{\mathrm{c}}$ & $0.051^{\mathrm{c}}$ \\
\hline & 21 & $0.18^{\mathrm{cd}}$ & $11.15^{\mathrm{d}}$ & $7.00^{\mathrm{b}}$ & $0.078^{b}$ \\
\hline & 28 & $0.16^{\mathrm{d}}$ & $10.18^{\mathrm{e}}$ & $9.00^{\mathrm{a}}$ & $0.102^{\mathrm{a}}$ \\
\hline & SEM & 0.02 & 0.05 & 0.01 & 0.000 \\
\hline & Source of variation & & & & \\
\hline & HS & $<0.001$ & $<0.001$ & $<0.001$ & $<0.001$ \\
\hline & Treatment & $<0.001$ & $<0.001$ & $<0.001$ & $<0.001$ \\
\hline & Storage time & $<0.001$ & $<0.001$ & $<0.001$ & $<0.001$ \\
\hline & HS*Treatment & $0.485^{\mathrm{NS}}$ & $<0.001$ & $<0.001$ & $<0.001$ \\
\hline & HS*DOS & $<0.001$ & $<0.001$ & $<0.001$ & $<0.001$ \\
\hline & Treatment*DOS & 0.001 & $<0.001$ & $<0.001$ & $<0.001$ \\
\hline
\end{tabular}

a-e Means in the same column with different superscripts are significantly different $(\mathrm{P}<0.05)$. SEM - standard error of mean. NS - not significant HS $=$ Housing system, DOS $=$ Duration of storage

Table 5: Effect of housing system and vitamin-mineral premix on egg white characteristics

\begin{tabular}{|c|c|c|c|c|c|c|c|c|c|}
\hline $\begin{array}{l}\text { Housing } \\
\text { system }\end{array}$ & $\begin{array}{l}\mathbf{V M} \\
\mathbf{P}\end{array}$ & $\begin{array}{c}\mathrm{SG} \\
\left(\mathrm{g} / \mathrm{cm}^{3}\right. \\
)\end{array}$ & $\begin{array}{l}\text { FC } \\
(\%)\end{array}$ & $\begin{array}{c}\text { FS } \\
(\%)\end{array}$ & $\begin{array}{c}\text { VS } \\
\text { (Centistoke } \\
\text { s) }\end{array}$ & $\begin{array}{c}\text { EC } \\
(\%)\end{array}$ & $\begin{array}{c}\text { ES } \\
(\%)\end{array}$ & LGC & $\begin{array}{c}\text { TBARS } \\
\text { (mg/MA/1 } \\
\text { 00g) }\end{array}$ \\
\hline & 1 & $1.18^{\mathrm{a}}$ & $25.29^{\mathrm{h}}$ & $21.90^{\mathrm{i}}$ & $32.53^{b}$ & $0.30^{\mathrm{bc}}$ & $15.82^{\mathrm{cd}}$ & $3.20^{\mathrm{i}}$ & $0.039^{f}$ \\
\hline & 2 & $1.17^{\mathrm{a}}$ & $50.69^{c}$ & $94.67^{\mathrm{a}}$ & $28.34^{\mathrm{c}}$ & $0.27^{\text {cde }}$ & $15.60^{d}$ & $4.80^{\mathrm{g}}$ & $0.041^{\mathrm{f}}$ \\
\hline \multirow{5}{*}{$\begin{array}{l}\text { Battery } \\
\text { cage }\end{array}$} & 3 & $1.22^{\mathrm{a}}$ & $54.64^{\mathrm{b}}$ & $70.12^{b}$ & $26.80^{\mathrm{e}}$ & $0.27^{\text {cde }}$ & $14.47^{\mathrm{f}}$ & $4.80^{\mathrm{g}}$ & $0.040^{\mathrm{f}}$ \\
\hline & 4 & $1.15^{\mathrm{a}}$ & $46.20^{\mathrm{d}}$ & $25.33^{\mathrm{h}}$ & $24.05^{\mathrm{g}}$ & $0.21^{\mathrm{de}}$ & $14.60^{f}$ & $6.20^{\mathrm{d}}$ & $0.048^{\mathrm{e}}$ \\
\hline & 5 & $1.16^{\mathrm{a}}$ & $31.29^{\mathrm{g}}$ & $19.11^{\mathrm{j}}$ & $22.76^{\mathrm{i}}$ & $0.20^{\mathrm{e}}$ & $14.10^{\mathrm{g}}$ & $6.63^{c}$ & $0.050^{\mathrm{e}}$ \\
\hline & 1 & $1.13^{\mathrm{ab}}$ & $24.07^{\mathrm{i}}$ & $59.64^{c}$ & $34.71^{\mathrm{a}}$ & $0.39^{\mathrm{a}}$ & $19.17^{\mathrm{a}}$ & $4.40^{\mathrm{h}}$ & $0.056^{\mathrm{d}}$ \\
\hline & 2 & $1.13^{\mathrm{a}}$ & $31.42^{\mathrm{g}}$ & $46.59^{e}$ & $28.21^{\mathrm{c}}$ & $0.32^{\mathrm{abc}}$ & $17.60^{\mathrm{b}}$ & $5.00^{\mathrm{f}}$ & $0.061^{b}$ \\
\hline \multirow[t]{4}{*}{ Deep litter } & 3 & $1.12^{\mathrm{c}}$ & $71.12^{\mathrm{a}}$ & $58.46^{\mathrm{d}}$ & $27.77^{d}$ & $0.37^{\mathrm{ab}}$ & $15.89^{c}$ & $6.00^{\mathrm{e}}$ & $0.059^{\mathrm{c}}$ \\
\hline & 4 & $1.12^{\mathrm{bc}}$ & $40.89^{\mathrm{e}}$ & $37.89 f$ & $25.37^{f}$ & $0.27^{\text {cde }}$ & $15.90^{\mathrm{c}}$ & $6.80^{\mathrm{b}}$ & $0.059 b^{c}$ \\
\hline & 5 & $1.12^{\mathrm{c}}$ & $35.01^{\mathrm{f}}$ & $31.22^{\mathrm{g}}$ & $23.03^{\mathrm{h}}$ & $0.29^{\mathrm{cd}}$ & $14.97^{\mathrm{e}}$ & $8.20^{\mathrm{a}}$ & $0.062^{\mathrm{a}}$ \\
\hline & SEM & 0.01 & 1.69 & 2.25 & 0.95 & 0.01 & 0.57 & 0.23 & 0.00 \\
\hline
\end{tabular}


Ogunwole

Table 6: Effect of housing system and duration of storage on egg white characteristics

\begin{tabular}{|c|c|c|c|c|c|c|c|c|c|}
\hline $\begin{array}{l}\text { Housing } \\
\text { system }\end{array}$ & $\begin{array}{l}\text { Duration } \\
\text { of } \\
\text { Storage }\end{array}$ & $\begin{array}{c}\mathrm{SG} \\
(\mathrm{g} / \mathrm{cm} \\
3 \\
\left.{ }^{2}\right)\end{array}$ & $\begin{array}{l}\text { FC } \\
(\%)\end{array}$ & $\begin{array}{l}\text { FS } \\
(\%)\end{array}$ & $\begin{array}{c}\text { VS } \\
\text { (centistoke } \\
\text { s) }\end{array}$ & $\begin{array}{l}\text { EC } \\
(\%)\end{array}$ & $\begin{array}{c}\text { ES } \\
(\%)\end{array}$ & LGC & $\begin{array}{c}\text { TBARS } \\
\text { (mg/MA/10 } \\
\text { 0g) }\end{array}$ \\
\hline \multirow{4}{*}{$\begin{array}{l}\text { Battery } \\
\text { cage }\end{array}$} & Day 0 & $1.23^{\mathrm{a}}$ & $48.06^{\mathrm{b}}$ & $63.87^{\mathrm{a}}$ & $46.80^{b}$ & $0.43^{b}$ & $28.12^{\mathrm{b}}$ & $2.83^{\mathrm{i}}$ & $0.007^{\mathrm{i}}$ \\
\hline & Day 7 & $1.15^{\mathrm{ab}}$ & $42.66^{\mathrm{c}}$ & $49.83^{\mathrm{d}}$ & $25.93^{\mathrm{d}}$ & $0.30^{\text {cd }}$ & $16.57^{\mathrm{d}}$ & $4.40^{\mathrm{f}}$ & $0.014^{\mathrm{g}}$ \\
\hline & Day 14 & $1.15^{\mathrm{ab}}$ & $41.28^{\mathrm{d}}$ & $42.71^{\mathrm{f}}$ & $24.26^{\mathrm{e}}$ & $0.22^{\mathrm{ef}}$ & $11.27^{\mathrm{h}}$ & $4.00^{\mathrm{g}}$ & $0.042^{\mathrm{e}}$ \\
\hline & Day 21 & $1.22^{\mathrm{ab}}$ & $39.91^{\mathrm{e}}$ & $38.91^{\mathrm{g}}$ & $20.85^{\mathrm{g}}$ & $0.15^{\mathrm{f}}$ & $10.11^{\mathrm{i}}$ & $6.00^{\mathrm{e}}$ & $0.068^{c}$ \\
\hline \multirow{7}{*}{ Deep litter } & Day 28 & $1.14^{\mathrm{ab}}$ & $36.21^{\mathrm{f}}$ & $35.81^{\mathrm{h}}$ & $16.64^{\mathrm{d}}$ & $0.15^{\mathrm{f}}$ & $8.53^{\mathrm{j}}$ & $8.40^{\mathrm{b}}$ & $0.088^{b}$ \\
\hline & Day 0 & $1.14^{\mathrm{ab}}$ & $69.04^{\mathrm{a}}$ & $57.42^{\mathrm{b}}$ & $49.13^{\mathrm{a}}$ & $0.64^{\mathrm{a}}$ & $28.81^{\mathrm{a}}$ & $2.80^{\mathrm{i}}$ & $0.011^{\mathrm{h}}$ \\
\hline & Day 7 & $1.12^{\mathrm{b}}$ & $41.17^{\mathrm{d}}$ & $34.15^{\mathrm{i}}$ & $28.24^{\mathrm{c}}$ & $0.37^{\mathrm{bc}}$ & $18.09^{c}$ & $3.20^{\mathrm{h}}$ & $0.024 f$ \\
\hline & Day 14 & $1.12^{\mathrm{ab}}$ & $33.43^{\mathrm{g}}$ & $55.73^{c}$ & $23.48^{\mathrm{f}}$ & $0.24^{\mathrm{de}}$ & $12.61^{\mathrm{e}}$ & $6.80^{\mathrm{d}}$ & $0.060^{\mathrm{d}}$ \\
\hline & Day 21 & $1.12^{\mathrm{b}}$ & $30.78^{\mathrm{h}}$ & $47.39^{\mathrm{e}}$ & $19.58^{\mathrm{h}}$ & $0.22^{\text {ef }}$ & $12.19^{\mathrm{f}}$ & $8.00^{c}$ & $0.088^{\mathrm{b}}$ \\
\hline & Day 28 & $1.11^{\mathrm{b}}$ & $28.10^{\mathrm{i}}$ & $39.12^{\mathrm{g}}$ & $17.67^{\mathrm{i}}$ & $0.17^{\text {ef }}$ & $11.83^{\mathrm{g}}$ & $9.60^{\mathrm{a}}$ & $0.12^{\mathrm{a}}$ \\
\hline & SEM & 0.01 & 1.69 & 2.25 & 0.95 & 0.01 & 0.57 & 0.23 & 0.00 \\
\hline
\end{tabular}
mineral premix. SG = Specific gravity, FC = Foaming capacity, FS= Foaming stability, VS = Viscosity, EC = Emulsion capacity, ES = Emulsion stability, $\mathbf{L G C}=$ Least gelation concentration, TBARS $=$ Thiobarbituric acid reactive substance. $1 \mathrm{cSt}(\mathrm{centistoke})=1 \mathrm{~mm}{ }^{2} / \mathrm{s}$.

\section{Specific gravity and functional properties} of the whole egg

Effect of five different proprietary $\mathrm{VmP}, \mathrm{HS}$ and DOS on foaming capacity of the whole egg is shown in Table 7. There were significant differences $(\mathrm{P}<0.05)$ in specific gravity of eggs from DL and BC. Specific gravity of eggs from hens fed VmP1 was similar to those of $\mathrm{VmP} 2,3$ and 5 but differed significantly from those on $\mathrm{VmP} 4$, which was similar $(\mathrm{P}>0.05)$ to those on $\mathrm{VmP} 3$ and 5. Specific gravity was highest at zero DOS and differed significantly from values in other DOS. At 7 and 14 DOS, specific gravity was similar which however, differed at 21 and 28 DOS.

The FC (39.20), foaming stability (17.94) and viscosity (23.31) of whole egg from $\mathrm{DL}$ were higher $(\mathrm{P}<0.05)$ than those from $\mathrm{BC}$. The highest $\mathrm{FC}$ was recorded in eggs from hens fed VmP 3 (40.18). However, the highest foaming stability (25.13) and viscosity (26.03) were observed in eggs from hens on diets $\mathrm{VmP} 4$ and 1 , respectively which differed $(\mathrm{P}<0.05)$ from others. Foaming capacity (56.94), foaming stability (35.30) and viscosity (45.84) of whole egg decreased significantly $(\mathrm{P}<0.05)$ to $20.40,9.65$ and 12.34 , respectively in DOS.
Functional properties and oxidative stability of whole egg

Effect of HS, VmP and DOS on functional properties and oxidative stability of whole egg is shown in Table 8. Emulsion capacity of eggs was not affected ( $\mathrm{P}>0.05)$ by HS. Emulsion stability, least gelation concentration and TBARS in DL $(0.35,7.32$ and 0.16 , respectively) were significantly higher $(\mathrm{P}<0.05)$ compared to those from BC. Eggs from hens on $\mathrm{VmP} 1$ had higher emulsion capacity compared with those on diets containing $\mathrm{VmP} 3,4$ and 5. However, DOS had significant effect on emulsion capacity $(\mathrm{P}<0.05)$ which was highest at day 0 (0.56) and lowest on day 28 (0.20). Emulsion stability differed significantly $(\mathrm{P}<0.05)$ with $\mathrm{VmP}$ and DOS. Emulsion stability decreased from 19.70 in eggs from hens on dietary VmP1 to 16.23 in VmP 5 also, from 32.24 on day 0 to 10.5 at day 28 .

Eggs from hens on VmP 5 had highest least gelation concentration $(8.50)$ which was significantly different $(\mathrm{P}<0.05)$ from those on VmP 1 (4.80), 2 (6.00), 3 (7.10) and 4 (7.10). Effect of DOS on least gelation concentration was also significant $(\mathrm{P}<0.05)$ which increased from 3.40 at day zero to 9.80 on 28 DOS. 


\section{Proprietary vitamin-mineral premixes and housing systems on egg properties and shelf-life stability}

Table 7: Effect of housing systems, vitamin-mineral premixes and duration of storage on specific gravity and functional properties of whole egg

\begin{tabular}{|c|c|c|c|c|c|}
\hline & Factors & $\begin{array}{l}\text { Specific } \\
\text { gravity } \\
\left(\mathrm{g} / \mathrm{cm}^{3}\right)\end{array}$ & $\begin{array}{l}\text { Foaming } \\
\text { capacity } \\
(\%)\end{array}$ & $\begin{array}{l}\text { Foaming } \\
\text { stability } \\
(\%)\end{array}$ & $\begin{array}{l}\text { Viscosity } \\
\text { (CentiStokes) }\end{array}$ \\
\hline Housing & Battery cage & $1.13^{\mathrm{a}}$ & $25.06^{\mathrm{b}}$ & $16.56^{\mathrm{b}}$ & $22.55^{\mathrm{b}}$ \\
\hline \multirow[t]{2}{*}{ System } & Deep litter & $1.11^{\mathrm{b}}$ & $39.20^{\mathrm{a}}$ & $17.94^{\mathrm{a}}$ & $23.31^{\mathrm{a}}$ \\
\hline & SEM & 0.001 & 0.03 & 0.03 & 0.03 \\
\hline Vitamin- & 1 & $1.12^{\mathrm{a}}$ & $25.15^{\mathrm{e}}$ & $13.75^{\mathrm{a}}$ & $26.03^{\mathrm{a}}$ \\
\hline Mineral & 2 & $1.12^{\mathrm{a}}$ & $39.37^{b}$ & $11.23^{\mathrm{e}}$ & $23.06^{b}$ \\
\hline \multirow[t]{4}{*}{ Premix } & 3 & $1.11^{\mathrm{a}, \mathrm{b}}$ & $40.18^{a}$ & $23.47^{\mathrm{b}}$ & $22.79^{\mathrm{c}}$ \\
\hline & 4 & $1.11^{\mathrm{b}}$ & $30.18^{\mathrm{c}}$ & $25.13^{\mathrm{c}}$ & $21.60^{\mathrm{d}}$ \\
\hline & 5 & $1.12^{\mathrm{a}, \mathrm{b}}$ & $25.79^{d}$ & $12.67^{\mathrm{d}}$ & $20.88^{d}$ \\
\hline & SEM & 0.002 & 0.05 & 0.04 & 0.04 \\
\hline Duration of & 0 & $1.17^{\mathrm{a}}$ & $56.94^{\mathrm{a}}$ & $35.30^{\mathrm{a}}$ & $45.84^{\mathrm{a}}$ \\
\hline \multirow[t]{13}{*}{ Storage } & 7 & $1.11^{\mathrm{b}}$ & $38.49^{b}$ & $17.70^{\mathrm{b}}$ & $22.01^{b}$ \\
\hline & 14 & $1.11^{\mathrm{b}}$ & $24.66^{\mathrm{c}}$ & $12.57^{\mathrm{c}}$ & $19.18^{\mathrm{c}}$ \\
\hline & 21 & $1.10^{\mathrm{c}}$ & $20.18^{d}$ & $11.03^{\mathrm{d}}$ & $15.29^{d}$ \\
\hline & 28 & $1.10^{\mathrm{c}}$ & $20.40^{\mathrm{e}}$ & $9.65^{\mathrm{e}}$ & $12.34^{\mathrm{e}}$ \\
\hline & SEM & 0.002 & 0.05 & 0.04 & 0.04 \\
\hline & Source of variation & & & & \\
\hline & HS & $<0.001$ & $<0.001$ & $<0.001$ & $<0.001$ \\
\hline & Treatment & 0.004 & $<0.001$ & $<0.001$ & $<0.001$ \\
\hline & DOS & $<0.001$ & $<0.001$ & $<0.001$ & $<0.001$ \\
\hline & HS*Treatment & 0.004 & $<0.001$ & $<0.001$ & $<0.001$ \\
\hline & HS*DOS & $<0.001$ & $<0.001$ & $<0.001$ & $<0.001$ \\
\hline & Treatment* DOS & 0.473 & $<0.001$ & $<0.001$ & $<0.001$ \\
\hline & HS*Treatment*DOS & 0.367 & $<0.001$ & $<0.001$ & $<0.001$ \\
\hline
\end{tabular}

${ }^{a-e}$ Means in the same column with different superscripts differs significantly $(\mathrm{P}<0.05)$. SEM- standard error of mean. $1 \mathrm{cSt}$ (centistoke) $1 \mathrm{~mm}^{2} / \mathrm{s}, \mathrm{HS}=$ Housing system, DOS=Duration of storage

Table 8: Effect of housing systems, vitamin-mineral premixes and duration of storage on functional properties and oxidative stability of whole egg

\begin{tabular}{|c|c|c|c|c|c|}
\hline & Factors & $\begin{array}{l}\text { Emulsion } \\
\text { capacity } \\
(\%)\end{array}$ & $\begin{array}{l}\text { Emulsion } \\
\text { stability } \\
(\%)\end{array}$ & $\begin{array}{l}\text { Least Gelation } \\
\text { Concentration }\end{array}$ & $\begin{array}{l}\text { TBARS } \\
(\mathrm{mg} / \mathrm{MA} / 100 \mathrm{~g})\end{array}$ \\
\hline \multirow{3}{*}{$\begin{array}{l}\text { Housing } \\
\text { system }\end{array}$} & Battery cage & $0.33^{\mathrm{a}}$ & $19.17^{\mathrm{a}}$ & $6.40^{\mathrm{a}}$ & $0.15^{b}$ \\
\hline & Deep litter & $0.35^{\mathrm{a}}$ & $16.09^{\mathrm{b}}$ & $7.32^{b}$ & $0.16^{\mathrm{a}}$ \\
\hline & SEM & 0.01 & 0.05 & 0.01 & 0.000 \\
\hline \multirow{6}{*}{$\begin{array}{l}\text { Vitamin- } \\
\text { mineral } \\
\text { premix }\end{array}$} & 1 & $0.40^{\mathrm{a}}$ & $19.70^{\mathrm{a}}$ & $4.80^{\mathrm{e}}$ & $0.155^{b}$ \\
\hline & 2 & $0.38^{\mathrm{a}, \mathrm{b}}$ & $18.22^{\mathrm{b}}$ & $6.00^{\mathrm{d}}$ & $0.156^{\mathrm{a}}$ \\
\hline & 3 & $0.33^{\mathrm{bc}}$ & $16.89^{\mathrm{d}}$ & $7.10^{c}$ & $0.156^{\mathrm{a}}$ \\
\hline & 4 & $0.30^{\mathrm{c}}$ & $17.11^{\mathrm{c}}$ & $7.90^{\mathrm{b}}$ & $0.153^{\mathrm{b}}$ \\
\hline & 5 & $0.29^{c}$ & $16.23^{\mathrm{e}}$ & $8.50^{\mathrm{a}}$ & $0.151^{\mathrm{c}}$ \\
\hline & SEM & 0.02 & 0.08 & 0.01 & 0.000 \\
\hline \multirow{14}{*}{$\begin{array}{l}\text { Duration of } \\
\text { storage }\end{array}$} & 0 & $0.56^{\mathrm{a}}$ & $32.24^{\mathrm{a}}$ & $3.40^{\mathrm{e}}$ & $0.010^{\mathrm{e}}$ \\
\hline & 7 & $0.38^{b}$ & $16.27^{\mathrm{b}}$ & $5.50^{\mathrm{d}}$ & $0.125^{\mathrm{d}}$ \\
\hline & 14 & $0.30^{\mathrm{c}}$ & $15.50^{\mathrm{c}}$ & $7.40^{\mathrm{c}}$ & $0.162^{\mathrm{c}}$ \\
\hline & 21 & $0.26^{\mathrm{c}}$ & $13.29^{\mathrm{d}}$ & $8.50^{\mathrm{b}}$ & $0.216^{\mathrm{b}}$ \\
\hline & 28 & $0.20^{\mathrm{d}}$ & $10.85^{e}$ & $9.80^{\mathrm{a}}$ & $0.256^{\mathrm{a}}$ \\
\hline & SEM & 0.02 & 0.08 & 0.01 & 0.000 \\
\hline & Source of variation & & & & \\
\hline & HS & $0.095^{\mathrm{NS}}$ & $<0.001$ & $<0.001$ & $<0.001$ \\
\hline & Treatment & $<0.001$ & $<0.001$ & $<0.001$ & $<0.001$ \\
\hline & DOS & $<0.001$ & $<0.001$ & $<0.001$ & $<0.001$ \\
\hline & HS*Treatment & $0.009^{\mathrm{NS}}$ & $<0.001$ & $<0.001$ & $<0.001$ \\
\hline & HS*DOS & $<0.001$ & $<0.001$ & $<0.001$ & $<0.001$ \\
\hline & Treatment*DOS & $0.414^{\mathrm{NS}}$ & $<0.001$ & $<0.001$ & $<0.001$ \\
\hline & HS*Treatment*DOS & $0.099^{\mathrm{NS}}$ & $<0.001$ & $<0.001$ & $<0.001$ \\
\hline
\end{tabular}

HS= Housing system, DOS=Duration of storage 


\section{Ogunwole}

The TBARS in eggs from hens on $\mathrm{VmP} 1$ $(0.155)$ and $4(0.153)$ were similar $(\mathrm{P}>0.05)$ but lower significantly $(\mathrm{P}<0.05)$ from those on $\operatorname{VmP} 2(0.156)$ and $3(0.156)$ and least (0.151) in eggs of those on VmP 5. The TBARS were higher $(\mathrm{P}<0.05)$ on 28 (0.256) DOS compared to other days and least at day $0(0.010)$.

Effect of housing system and vitaminmineral premix on whole egg attributes

Effect of interaction of $\mathrm{HS}$ and $\mathrm{VmP}$ on whole egg attributes is shown in Table 9. Interaction of $\mathrm{HS}$ and $\mathrm{VmP}$ on specific gravity of whole eggs from hens on $\mathrm{VmP}$ 1(1.13) was similar $(\mathrm{P}>0.05)$ to those on VmP 2 (1.124), 3 (1.124), 4 (1.121) and 5 (1.128) in BC which however differed $(\mathrm{P}<0.05)$ from those in DL. Specific gravity of eggs from hens on VmP 1(1.110) in DL was similar to those on VmP3 (1.105) and 4
(1.105) but higher $(\mathrm{P}<0.05)$ compared with those on VmP5 (1.102).

The FC, foaming stability, viscosity, emulsion capacity, least gelation concentration and TBARS of egg from hens on different $\mathrm{VmP}$ were higher in DL than in BC except for those from hens VmP 3 where foaming capacity (29.58) and foaming stability (28.627) of eggs in BC were higher compared with those on $\mathrm{VmP} 3$ in DL (26.740 and 18.307, respectively) Also, FC (23.77) and viscosity (21.13) of eggs from hens on VmP 5 in BC were higher than those on VmP 5 (19.053 and 20.631, respectively) in DL. Foaming capacity $(\%)$ across all $\mathrm{VmP}$ in both $\mathrm{HS}$ differed significantly $(\mathrm{P}<0.05)$. Interaction of DL and VmP 2 resulted in higher FC $(40.92 \%)$ which was least (17.99) in eggs of hens on $\mathrm{VmP} 1$ in $\mathrm{BC}$.

Table 9: Effect of housing system and vitamin-mineral premix on whole egg

\begin{tabular}{|c|c|c|c|c|c|c|c|c|c|}
\hline $\begin{array}{l}\text { Housing } \\
\text { system }\end{array}$ & VMP & $\begin{array}{r}\text { SG } \\
\left(\mathrm{g} / \mathrm{cm}^{3}\right) \\
\end{array}$ & $\begin{array}{r}\text { FC } \\
(\%)\end{array}$ & $\begin{array}{r}\text { FS } \\
(\%)\end{array}$ & $\begin{array}{r}\mathrm{VS} \\
\text { (centistokes) } \\
\end{array}$ & $\begin{array}{r}\text { EC } \\
(\%)\end{array}$ & $\begin{array}{r}\text { ES } \\
(\%)\end{array}$ & LGC & $\begin{array}{l}\text { TBARS } \\
(\mathrm{mg} / \mathrm{MA} / \mathbf{1 0 0 g})\end{array}$ \\
\hline Battery & $\mathrm{T} 1$ & $1.13^{\mathrm{a}}$ & $17.987^{\mathrm{i}}$ & $7.960^{\mathrm{i}}$ & $25.464^{b}$ & $0.353^{b c}$ & $20.933^{a}$ & $4.200^{\mathrm{d}}$ & $0.147^{\mathrm{f}}$ \\
\hline \multirow[t]{5}{*}{ Cage } & $\mathrm{T} 2$ & $1.124^{\mathrm{a}}$ & $30.880^{\mathrm{b}}$ & $7.493^{j}$ & $22.047^{\mathrm{f}}$ & $0.400^{\mathrm{ab}}$ & $19.213^{\mathrm{b}}$ & $5.400^{\mathrm{cd}}$ & $0.146^{\mathrm{f}}$ \\
\hline & $\mathrm{T} 3$ & $1.124^{\mathrm{a}}$ & $29.580^{c}$ & $28.627^{\mathrm{a}}$ & $22.313^{\mathrm{e}}$ & $0.307^{\mathrm{c}}$ & $18.107^{d}$ & $6.800^{\mathrm{bc}}$ & $0.142^{\mathrm{g}}$ \\
\hline & $\mathrm{T} 4$ & $1.121^{\mathrm{ab}}$ & $23.100^{\mathrm{g}}$ & $26.813^{b}$ & $21.801^{\mathrm{g}}$ & $0.287^{\mathrm{c}}$ & $19.027^{\mathrm{b}}$ & $7.200^{\mathrm{ab}}$ & $0.153^{\mathrm{de}}$ \\
\hline & $\mathrm{T} 5$ & $1.128 \mathrm{a}$ & $23.773^{\mathrm{f}}$ & $11.927^{\mathrm{h}}$ & $21.133^{\mathrm{i}}$ & $0.300^{c}$ & $18.587^{\mathrm{c}}$ & $8.400^{\mathrm{a}}$ & $0.147^{\mathrm{f}}$ \\
\hline & $\mathrm{T} 1$ & $1.110^{\mathrm{cd}}$ & $27.867^{\mathrm{d}}$ & $19.540^{\mathrm{d}}$ & $26.604^{\mathrm{a}}$ & $0.447^{\mathrm{a}}$ & $18.467^{\mathrm{c}}$ & $5.400^{\mathrm{b}}$ & $0.161^{\mathrm{c}}$ \\
\hline Deep & $\mathrm{T} 2$ & $1.114^{\mathrm{bc}}$ & $40.920^{\mathrm{a}}$ & $14.967^{\mathrm{f}}$ & $24.075^{c}$ & $0.353^{b c}$ & $17.220^{\mathrm{e}}$ & $6.600^{\mathrm{ab}}$ & $0.167^{b}$ \\
\hline \multirow[t]{4}{*}{ Litter } & $\mathrm{T} 3$ & $1.105^{\mathrm{cd}}$ & $26.740^{\mathrm{e}}$ & $18.307^{\mathrm{e}}$ & $23.820^{\mathrm{d}}$ & $0.347^{\mathrm{bc}}$ & $15.680^{f}$ & $7.400^{\mathrm{ab}}$ & $0.170^{\mathrm{a}}$ \\
\hline & $\mathrm{T} 4$ & $1.105^{\mathrm{cd}}$ & $30.967^{b}$ & $23.447^{\mathrm{c}}$ & $21.401^{\mathrm{h}}$ & $0.320^{\mathrm{bc}}$ & $15.193^{\mathrm{g}}$ & $8.600^{\mathrm{a}}$ & $0.152^{\mathrm{e}}$ \\
\hline & $\mathrm{T} 5$ & $1.102^{\mathrm{d}}$ & $19.053^{\mathrm{h}}$ & $13.420^{\mathrm{g}}$ & $20.631^{\mathrm{j}}$ & $0.287^{\mathrm{c}}$ & $13.873^{\mathrm{a}}$ & $8.600^{\mathrm{a}}$ & $0.155^{\mathrm{d}}$ \\
\hline & SEM & 0.00 & 1.18 & 1.08 & 1.00 & 0.01 & 0.66 & 0.23 & 0.01 \\
\hline
\end{tabular}

Effect of housing system and duration of storage on whole egg attributes

Interaction of HS and DOS on attributes of whole egg is shown in Table 10. Specific gravity of eggs from BC at day 0 (1.213) was significantly higher $(\mathrm{P}<0.05)$ than those from $\mathrm{BC}(1.123)$ at zero DOS. However, specific gravity of corresponding eggs from hens in $\mathrm{BC}$ (1.106 and 1.095) and
DL (1.107 and 1.095) at 14 and 28 DOS, respectively were similar $(\mathrm{P}>0.05)$. Foaming capacity across all DOS in both HS were significantly different $(\mathrm{P}<0.05)$. Interaction of DL $\mathrm{X}$ zero DOS on FC (\%) was higher (49.620) and least in (13.847) BC X 28 DOS. Foaming stability differed significantly $(\mathrm{P}<0.95)$ across all DOS in both HS. Interaction of DL X zero DOS on 
foaming stability (\%) was higher (38.48) but lowest (8.347) for BC X 28 DOS.

The viscosity of egg white from hens in BC at zero DOS (46.346) was significantly higher $(\mathrm{P}<0.05)$ than for corresponding eggs from DL (45.332) and all other days in both HS. The lowest viscosity (9.673) was in eggs from $\mathrm{BC}$ at 28 DOS. However, emulsion capacity (\%) in egg white from BC (0.620) at zero DOS was significantly higher $(\mathrm{P}<0.05)$ than corresponding ones from DL (0.507) and others across both HS and DOS. Emulsion capacity of eggs from $\mathrm{BC}$ at 14 DOS (0.313) was similar to those from DL at 21 DOS (0.340). Least emulsion capacity (0.140) was observed in eggs from $\mathrm{BC}$ at $28 \mathrm{DOS}$.

Emulsion stability differed significantly $(\mathrm{P}<0.05)$ in eggs from $\mathrm{BC}$ at zero DOS and others. However, there was similarity in observed values for eggs in $\mathrm{BC}$ on 14 DOS (15.647) and corresponding value in DL (15.353). Similar trends were observed in whole eggs from DL and BC on 21 (13.273 and 13.313) and 28 (11.007 and 10.700) DOS. Emulsion stability of BC eggs at 7 DOS (19.967) was also significantly different from others. Least gelation capacity was highest (10.400) in DL at 28 DOS which was similar $(\mathrm{P}>0.05)$ to corresponding values for eggs from $\mathrm{BC}$ (9.200). This trend was observed across all other DOS in both HS. The TBARS $(\mathrm{mg} / \mathrm{MA} / 100 \mathrm{~g})$ was highest $(\mathrm{P}<0.05)$ (0.276) in DL whole eggs at 28 DOS compared to corresponding 0.236 in $\mathrm{BC}$ and all others. However, similar $(\mathrm{P}>0.05)$ TBARS of 0.125 was obtained in whole eggs from BC and DL at 7 DOS. The lowest TBARS $(\mathrm{P}<0.05)$ of 0.008 was observed in $\mathrm{BC}$ at zero DOS.

Table 10: Effect of housing system and vitamin-mineral premix on attributes of whole egg

\begin{tabular}{|c|c|c|c|c|c|c|c|c|c|}
\hline $\begin{array}{l}\text { Housing } \\
\text { System }\end{array}$ & $\begin{array}{l}\text { Duration } \\
\text { of } \\
\text { storage }\end{array}$ & $\begin{array}{r}\mathrm{SG} \\
\left(\mathrm{g} / \mathrm{cm}^{3}\right)\end{array}$ & $\begin{array}{r}\text { FC } \\
(\%)\end{array}$ & $\begin{array}{r}\text { FS } \\
(\%)\end{array}$ & $\begin{array}{r}\mathrm{VS} \\
\text { (centistokes) }\end{array}$ & $\begin{array}{r}\text { EC } \\
(\%)\end{array}$ & $\begin{array}{r}\text { ES } \\
(\%)\end{array}$ & LGC & $\begin{array}{l}\text { TBARS } \\
\text { (mg/MA/ } \\
\text { 100g) }\end{array}$ \\
\hline & Day 0 & $1.213^{\mathrm{a}}$ & $44.840^{b}$ & $32.113^{b}$ & $46.346^{\mathrm{a}}$ & $0.620^{\mathrm{a}}$ & $36.240^{\mathrm{a}}$ & $3.600^{\mathrm{e}}$ & $0.008^{i}$ \\
\hline Battery & Day 7 & $1.110^{\mathrm{cd}}$ & $27.360^{d}$ & $17.767^{\mathrm{c}}$ & $23.707^{c}$ & $0.400^{\mathrm{c}}$ & $19.967^{\mathrm{c}}$ & $5.200^{\mathrm{d}}$ & $0.125^{\mathrm{g}}$ \\
\hline \multirow[t]{4}{*}{ Cage } & Day 14 & $1.106^{\text {cde }}$ & $21.653^{\mathrm{g}}$ & $13.760^{\mathrm{d}}$ & $19.447^{\mathrm{e}}$ & $0.313^{\text {cde }}$ & $15.647^{d}$ & $6.400^{\mathrm{c}}$ & $0.166^{\mathrm{e}}$ \\
\hline & Day 21 & $1.102^{\text {def }}$ & $17.620^{\mathrm{i}}$ & $10.833^{f}$ & $13.587^{\mathrm{i}}$ & $0.173^{\mathrm{fg}}$ & $13.313^{\mathrm{e}}$ & $7.600^{\mathrm{b}}$ & $0.199^{\mathrm{d}}$ \\
\hline & Day 28 & $1.095^{\mathrm{f}}$ & $13.847^{\mathrm{h}}$ & $8.347^{\mathrm{g}}$ & $9.673^{\mathrm{e}}$ & $0.140^{\mathrm{g}}$ & $10.700^{\mathrm{g}}$ & $9.200^{\mathrm{a}}$ & $0.236^{\mathrm{b}}$ \\
\hline & Day 0 & $1.123^{b}$ & $49.620^{\mathrm{a}}$ & $38.480^{\mathrm{a}}$ & $45.332^{\mathrm{b}}$ & $0.507^{b}$ & $28.233^{b}$ & $3.200^{\mathrm{e}}$ & $0.012^{\mathrm{h}}$ \\
\hline Deep & Day 7 & $1.112^{\mathrm{c}}$ & $27.673^{c}$ & $17.627^{\mathrm{c}}$ & $20.307^{d}$ & $0.353^{\mathrm{cd}}$ & $12.567^{\mathrm{f}}$ & $5.200^{\mathrm{d}}$ & $0.125^{\mathrm{g}}$ \\
\hline \multirow[t]{3}{*}{ Litter } & Day 14 & $1.107^{\text {cde }}$ & $26.947^{\mathrm{e}}$ & $11.387^{\mathrm{e}}$ & $18.907^{\mathrm{f}}$ & $0.293^{\mathrm{de}}$ & $15.353^{\mathrm{d}}$ & $8.400^{c}$ & $0.159^{f}$ \\
\hline & Day 21 & $1.098^{\mathrm{ef}}$ & $22.733^{f}$ & $11.227^{\mathrm{e}}$ & $16.987^{\mathrm{g}}$ & $0.340^{\text {cde }}$ & $13.273^{\mathrm{e}}$ & $9.400^{\mathrm{b}}$ & $0.234^{\mathrm{c}}$ \\
\hline & Day 28 & $1.095^{\mathrm{f}}$ & $18.573^{\mathrm{j}}$ & $10.960^{f}$ & $15.000^{\mathrm{h}}$ & $0.260^{\mathrm{ef}}$ & $11.007^{\mathrm{g}}$ & $\begin{array}{r}10.40 \\
0^{\mathrm{a}}\end{array}$ & $0.276^{\mathrm{a}}$ \\
\hline
\end{tabular}

${ }^{\mathrm{a}-\mathrm{i}}$ Means in the same column with different superscripts differs significantly $(\mathrm{P}<0.05)$. SEM- standard error of mean. VMP $=$ Vitamin-mineral premix. $\mathrm{SG}=$ Specific gravity, $\mathrm{FC}=$ Foaming capacity, $\mathrm{FS}=$ Foaming stability, $\mathrm{VS}=$ Viscosity, $\mathrm{EC}=$ Emulsion capacity, $\mathrm{ES}=$ Emulsion $\mathrm{st}$ ability, $\mathrm{LGC}=\mathrm{Least}$ gelation concentration, TBARS $=$ Thiobarbituric acid reactive substance. $1 \mathrm{cSt}($ centistoke $)=1 \mathrm{~mm}^{2} / \mathrm{s}$.

\section{Discussion}

\section{Properties of egg white}

\section{Specific gravity}

There was lowered specific gravity of egg white from hens in the DL compared with those from BC. This could be because eggs from $\mathrm{BC}$ were not in contact with droppings of hens. This conforms to the report of
Sekeroglu et al. (2008) on observed differences in the eggs from DL, free-range and cage systems. Though, specific gravity decreased as DOS increased which corresponds to the report of Sekeroglu et al. (2008) that extension in DOS decreases egg specific gravity. However, effect of storage on specific gravity of egg white in this study 


\section{Ogunwole}

was not significantly different. This contrasted the findings of Hasan and Aylin (2009) of clear negative effect of storage durations and temperature at week 50 on the specific gravity of eggs and that DOS and temperature were found to be important in keeping eggs fresh. In this study, interaction effect of HS and DOS on specific gravity of eggs was not significant as earlier documented (Sekeroglu et al., 2008) that the interaction of HS and DOS was not significantly different for observed attributes of eggs except yolk colour. However, Sekeroglu et al. (2008) surmised that storage length affected egg albumen quality more compared with yolk. Additionally, increased DOS decreased overall egg quality characteristics.

\section{Foaming and emulsifying properties}

Higher FC and foaming stability observed in eggs from $\mathrm{BC}$ agreed with the findings of Alamprese et al. (2012) that better foaming properties were obtained in eggs from cage and organic poultry. The foam consistency index, overrun and hen age seemed to be affected by HS. As reported (Jones et al., 2014), barn eggs showed slightly lower foaming performance, but had similar foam instability as cage eggs. Wang and Narsimhan (2004) further posited that other than the differences in egg weight at wk 4 of cold storage, no significant differences were observed in rate of quality decline among the HS. Earlier studies (Jones et al., 2014) surmised that increased dietary protein concentration resulted in increase foaming capacity because of higher rate of protein adsorption at the air-water interface and subsequent reduction in surface tension. However, differences observed in this study could not be ascribed to variations in protein content of the diets fed to hens in both HS which were isonitrogenous. Foaming properties of proteins are also influenced by environmental factors like ionic strength or pH. Kuropatwa et al. (2009) demonstrated that large variations in $\mathrm{pH}$ affect egg white foaming performances: the best foam characteristics were obtained at $\mathrm{pH} 5$ than at pH 7 and 9. It should be noted however, that differences in foaming properties on the basis of HS, even if statistically significant, were small and unlikely to have real effects when the eggs were used in food preparations. Hammershøj and Qvist (2001) in a study on eggs from white Leghorn hens in cages, observed a slight decrease in foam overrun as a function of hen age in the thin albumen. It was therefore concluded that hen strains are important in determining albumen foaming properties during the laying cycle. In this study, the foaming capacity of egg white decreased as DOS increased which contrasted report of Silversides et al. (2004) that stale egg white has maximum foaming ability compared to fresh egg white

\section{Albumen viscosity}

The viscosity of eggs across both HS decreased with increasing DOS. This could be due to gradual evaporation of water through the shell which causes a decrease in density as the air cells enlarge. This agrees with the report of Caner and Yusser (2015) that the viscosity of egg albumen decreased during storage which also confirms earlier submissions (Kemps, et al., 2010; Kannan, et al., 2013).

\section{Effect of HS, DOS and VmP on TBARS of egg white}

The observed higher MDA of egg albumen from hens fed VmP 5 could be attributed to the noted relatively higher levels of vitamin $\mathrm{E}$ and $\mathrm{B} 6$ as well as the minerals zinc, iron, manganese and selenium content in the VmP. Vitamin $\mathrm{E}$ has been reported by Halliwell et al. (1995) to protect cells from reactive oxygen species in vivo. Cherian et al. (1996) posited that vitamin E maintains 
oxidative stability and vitamin B6 improves egg quality. Organic trace minerals such as iron, selenium, manganese and zinc increased the shelf life of eggs which all agreed with the observations in this study. Highest MDA due to interactive effect of DL and 28 DOS was because deterioration in eggs begins as soon as the egg is laid and continues until the egg is consumed.

\section{Properties of whole egg \\ Specific gravity}

The specific gravity of whole egg was lowered in DL compared to BC. This could be due to relatively neater eggs from $\mathrm{BC}$ as earlier observed (Sekeroglu et al., 2008) that advancing DOS decreased egg specific gravity. Increased DOS lowers overall egg quality characteristics because eggs lose their quality rapidly between the period of collection and consumption. Highest specific gravity recorded at zero DOS due to interactive effect of HS and DOS in both DL and BC could be because freshly laid eggs have all their properties intact and the deterioration was slower until after it has stayed for over 24 hours (Blokhuis et al., 2007; Ogunwole et al., 2015b)

\section{Foaming and emulsifying properties}

Foaming capacity and stability for whole egg in this study were than those of egg white. This could be because egg yolk was also mixed. This agrees with the report of Kim and Setser (1982) as cited by Lomakina and Mikova (2006) that the presence of even small quantities of yolk decreases albumen foaming ability. Aro et al. (2011) earlier reported that fish oil supplementation in feed influences foaming properties of fresh eggs and eggs stored for 21 days lost part of their foaming properties in fish oil supplemented group. This conforms to the result of this study that composition of the diet in terms of the different $\mathrm{VmP}$ may affect foaming properties. The interactive effect of HS and treatment on foaming capacity and stability of whole egg could be attributed to the fact that $\mathrm{BC}$ and DL HS influenced foaming properties of eggs. The emulsifying properties of eggs in fish oil and fish supplemented groups differed compared to control group. This could be because eggs also undergo a sequence of interior (functional) quality changes and microbial contamination during storage (Jones et al., 2004).

\section{Viscosity of whole egg}

As was observed for egg white, viscosity of whole egg reduced with different $\mathrm{VmP}$ and DOS. However, whole egg had lower viscosity than egg white which could be due to the presence of yolk.

Effect of HS, DOS and vitamin-mineral premix on TBARS of whole egg

The MDA of whole egg was also highest on 28 DOS and was significantly different from values observed at 0 DOS. This could be because rate of deterioration of egg increases as DOS increased. Sekeroglu et al. (2008) earlier stated that eggs may lose their quality rapidly between the period of collection and consumption. The TBARS of whole egg in this study were observed to be higher in all the factors considered (HS, $\mathrm{VmP}$ and DOS) compared with the corresponding egg white. This could be attributed to the fact that egg yolks contain more fat than the albumen portion and are perhaps more prone to deterioration by reactive oxygen species.

\section{Conclusion}

The study showed that egg functional properties were affected by the different dietary VmP. The synergistic effect of HS and VmP did not affect overall acceptability. Therefore, the duration of storage facilitated deterioration of eggs and affected properties of egg in spite of HS and dietary supplement of VmP. 
Acknowledgement

This publication is a memoir and a tribute in honour of a very humble, forthright, hardworking and amiable graduate student, Miss Lovet Anwuli Dibia whose life was suddenly terminated by the wicked cold hands of death. Her diligence, doggedness and industry were invaluable to the actualization of this research. I also appreciate the assiduous contributions and supports of Dr A. Y. P. Ojelade and every graduate student under my supervision in collation and editing of this masterpiece.

\section{References}

Alamprese, C., Casiraghi, E. and Rossi, M. 2012. Foaming, gelling and rheological properties of egg albumen as affected by the housing system and the age of laying hens. International Journal of Food Science and Technology, 47: 1411-1420.

Aro, H., Rokka, T. Valaja, J., Hiidenhovi, J., Hulopalahti, R. and RyhÃănen, E. L. 2011. Functional and sensory properties of hen eggs with modified fatty acid compositions. Food function, 4: 671-677.

Asaduzzman, M., Jahan, M.S., Mondol, M. R., Islam, M. A. and Sarkar, A. K. 2005. Efficacy of Different commercial vitamin-mineral premixes on productive performance of caged laying pullets. International Journal of Poultry Science 4, (98): 589-595.

Beneda, S., LApez- ExpAsito, I., Molina, E. and LApez-fandiA, R. 2014. Egg proteins as allergens and the effects of the food matrix and processing. Food Function, 6: 694-713.

Blokhuis, H. J., Van Niekerk, T. F.,
Bessei, W., Elson, A., Guemene, D., Kjaer, J. B., Levrino, G.A., Nicole, C. J., Tauson, R., Weeks, C.A. and De Weerd, H. A. 2007. The LayWel project: welfare implications of changes in production systems for laying hens. World Poultry Science Journal, 63:101-114.

Cherian, G., Wolfe, F. W. and Sim, J. S. 1996. Feeding dietary oils with tocopherols: Effects on internal qualities of eggs during storage. Journal of Food Scence, 61:15-18.

Hammershøj, M. and Qvist, K. B. 2001. Importance of hen age and egg storage time for egg albumen foaming. LebensmittelWissenschaft and Technologie, 34:118-120.

Hasan, A. and Aylin, A. O. 2009. Effect of storage time, temperature and hen age on egg quality in free-range layer hens. Journal of Animal and Veterinary Advances 8, (10): 1953195.

Hayat, Z., Cherian, G., Pasha, T. N., Khattak, F. M. and Jabbar, M. A. 2010. Sensory evaluation and consumer acceptance of eggs from hens fed flax-seed and 2 different antioxidants. Poultry Science, 89 (10): 2293 - 8. Doi: 10.3382/ps. 2009-00575.

Hernandez-Ledesma, B. and ChiaChien, H. 2013. Functional proteins and peptides of hen's egg origin. Chapter 5.115-116 in Bioactive Food Peptides in Health and Disease. A. M. Abdou, M. Kim, and K. Sato eds.

Jones, D. R., Musgrove, M. T. and Northcutt. J. K. 2004. Variations in External and Internal Microbial 
Populations in Shell Eggs during Extended Storage. Journal of Food Protection, 67: 2657-2666.

Jones, D. R., Karcher, D. M. and Abdo, Z. 2014. Effect of a commercial housing system on egg quality during extended storage. Poult Sci, $93(5): 1282-8$. d o i : 10.3382/ps.2013-03631.

Kannan, S., Dev, S. R. S., Gariepy, Y. and Raghavan, G. S. V.2013. Effect of radiofrequency heating on the dielectric and physical properties of eggs. Progress In Electromagnetics Research B 51:201-220.

Kemps, B. J., Bamelis, F. R., Mertens, K., Decuypere, E. M., De Baerdemaeker, J. G. and De Ketelaere, B. 2010. The assessment of viscosity Measurements on the albumen of consumption eggs as an indicator for freshness. Poult. Sci, $89: 2699-2703$. D o i 10.3382/ps.2008-00520.

Kim, K. and Setser, C. S. 1982. Foaming properties of fresh and commercially dried eggs in the presence of stabilizers and surfactants. Poultry Science, 61: 2194-2199.

Kuropatwa, M., Tolkach, A. and Kulozik, U. 2009. Impact of $\mathrm{pH}$ on the interactions between whey and egg white proteins as assessed by the foamability of their mixtures. Food Hydrocolloids, 23, 2174-2181.

Lomakina, K. and Mikova, K. 2006. A study of the factors affecting the foaming properties of egg white A review. Czech Journal of Food Science, 24: 110-118.

Matt, D., Vermann, E. and Luik, A. 2009.
Effect of housing system on biochemical composition of chicken eggs. Agronomy Research 7 (Special Issue II), 662-667.

Montagne, P. 2001. Larousse Gastronomique, Clarkson Potter. pp. 447-448. ISBN 0-609-60971-8

Ogunwole, O. A., Kolade, E. $O$ and Taiwo, B. A. 2012. Performance and carcass characteristics of broilers fed five different commercial vitamin-mineral premixes in Ibadan, Nigeria International Journal of Poultry Science, 11 (2): 120-124

Ogunwole, O. A., Ojelade, A. Y. P., Oyewo, M. O. and Essien, E. A. 2015a. Proximate composition and physical characteristics of eggs from laying chickens fed different proprietary vitamin-mineral premix under two rearing systems during storage. International Journal of Food Science and Nutrition Engineering, 5 (1): 5967. DOI: $10.5923 / \mathrm{j}$. food. 20150501.08

Ogunwole, O. A., Ojelade, A. Y. P., Essien, E. A. and Oyewo, M. O. 2015b. Lipid profile of eggs from laying chickens fed five proprietary vitamin-mineral premixes under two rearing systems as influenced by duration of storage. Food and Public Health, 5 (1): 10-16. DOI: 10. 5923/j.fph.20150501.02

Parpinello, G. P., Meluzzi, A., Sirri, F., Tallarico, N. and Versari, A. 2010. Sensory evaluation of egg products and eggs laid from hens fed diets with different fatty acid composition and supplemented with antioxidants. Food Research International 39(1): 47-52. 


\section{Ogunwole}

Patricio, I. S. 2003. Manejo do ovo incubável da granja ao incubatório. In: Macari M, Gonzales: Facta. Pp. 163-179.

SAS, 2012. SAS STAT User's Guide Institute Inc. Release 6.08. SAS Institute Inc., Cary, NC.

Şekeroğlu, A., Sarica, M., Demir, E., Ulutaş, Z., Tilki, M. and Saateı, M. 2008. The effects of housing system and storage length on the quality of eggs produced by two lines of laying hens -Einfluss des Haltungssystems und der Lagerdauer auf die Qualität von

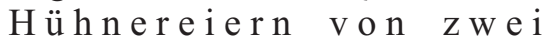
Legeherkünften Arch.Geflügelk., 72 ( 3). S. 106- 109. ISSN 00039098. (C) Verlag Eugen Ulmer, Stuttgart

Silversides, F. G. and Budgell, K. 2004: The relationships among measures of egg albumen height, $\mathrm{pH}$, and whipping value. Poultry Science, 83: 1619-1623. Silversides, F., and T. Scott. 2001. Effect of storage and layer age on quality of eggs from two lines of hens. Poult. Sci. 80: 1240-1245.
Surai, P., Ionov, I., Buzhin, A. and Buzhina, N. 1997. Vitamin E and egg quality. Pages 387-394 in Proceedings of the $7^{\text {th }}$ European Symposium on the Quality of Eggs and Egg Products, Poznan, Poland, Zaklad Poligraficzny "Graf-Com," Poznan, Poland.

Theoron, H., Venter, P. and Lues, J. F. R. 2003. Bacterial growth on chicken eggs in various storage environments. Food Research International, 36: 969-975.

Received: 10th July, 2017

Accepted: $9^{\text {th }}$ December, 2017 